\title{
РАЗРАБОТКА И ИССЛЕДОВАНИЕ ПОЛЕВЫХ ЭМИТТЕРОВ ДЛЯ КОРОТКОВОЛНОВЫХ СВЧ ПРИБОРОВ В СПбПУ. ПОСЛЕДНИЕ ДОСТИЖЕНИЯ*
}

\author{
Г. Г. Соминский, В. Е. Сезонов, Т. А. Тумарева, Е. П. Тарадаев \\ Санкт-Петербургский политехнический университет Петра Великого \\ Россия, 195251 Санкт-Петербург, Политехническая ул., д.29 \\ E-mail: sominski@rphf.spbstu.ru, sezonovve@mail.ru, \\ tumareva@rphf.spbstu.ru, evgeny_tar@hotmail.com \\ Поступила в редакцию 5.04.2018
}

Тема и цель исследования. Приведены данные о последних достижениях авторов по разработке и исследованию полевых эмиттеров для электроннопучковых СВЧ приборов миллиметрового и субмиллиметрового диапазона длин волн. Методы. Описаны методы создания и характеристики представляющих большой практический интерес катодов нового типа: многоострийных кремниевых катодов с двухслойными металлфуллереновыми покрытиями, а также многослойных нано-структурированных катодов, эмиссия которых определяется полями у контакта материалов с разной работой выхода. Для оптимизации катодов и определения их эмиссионных характеристик проводились численные расчеты и экспериментальные исследования. Важнейшие отличительные черты использованных экспериментальных установок: • возможно оперативное изменение давления от минимального $10^{-9}-10^{-10}$ Torr до $10^{-6}$ Torr и обратно; • возможно проведение ряда технологических операций непосредственно в вакуумной камере, в том числе, по нанесению и обработке покрытий; • возможно исследование эмиссионных характеристик катодов в непрерывном и импульсном режимах в широком интервале напряжений (до 15-25 kV) и токов (до 0.5 А). Результаты. Получено большое количество новых результатов, в том числе: - отработаны достаточно простые и воспроизводимые технологии создания многоострийных и многослойных эмиттеров; • определен механизм фрунцционирования защитных фуллереновых покрытий; • определены оптимальные структура и морфология поверхности многоострийных катодов с металл-фруллереновыми покрытиями и продемонстрирована возможность получения с их помощью токов полевой эмиссии приблизительно до $100 \mathrm{~mA}$ при плотности тока до $0.4 \mathrm{~A} / \mathrm{cm}^{2}$; • определена оптимальная структура многослойных гафний-платиновых катодов и продемонстрирована возможность получения с их помощью токов эмиссии около $2 \mathrm{~mA}$ при чрезвычайно большой плотности тока около $200 \mathrm{~A} / \mathrm{cm}^{2}$; ・ продемонстрирована возможность длительной стабильной работы созданных катодов при отборе больших токов в условиях технического вакуума. Обсуждение. Созданные и исследованные катоды перспективны для использования в миниатюрных высоковольтных электронно-пучковых СВЧ устройствах миллиметрового и субмиллиметрового диапазона. 
Ключевые слова: полевая эмиссия, многоострийные катоды, многослойные катоды, технический вакуум, ионная бомбардировка, двухслойные металл-фуллереновые покрытия, поля контактной разности потенциалов, коротковолновые электронно-пучковые СВЧ приборы.

DOI: 10.18500/0869-6632-2018-26-3-109-126

Образец цитирования: Соминский Г.Г., Сезонов В.Е., Тумарева Т.А., Тарадаев Е.П. Разработка и исследование полевых эмиттеров для коротковолновых СВЧ приборов в СПБПУ. Последние достижения // Известия вузов. Прикладная нелинейная динамика. 2018. T. 26, No 3. C. 109-126. DOI: 10.18500/0869-6632-2018-26-3-109-126

\title{
DEVELOPMENT OF FIELD EMITTERS FOR SHORT WAVE MICROWAVE DEVICES AND THEIR INVESTIGATION IN SPbPU. THE LAST ACHIEVEMENTS
}

\author{
G. G. Sominskii, V. E. Sezonov, T. A. Tumareva, E. P. Taradaev \\ Peter the Great St.Petersburg Polytechnic University \\ 29, Polytechnic Str., 195251 St. Petersburg, Russia \\ E-mail: sominski@rphf.spbstu.ru, sezonovve@mail.ru, \\ tumareva@rphf.spbstu.ru, evgeny_tar@hotmail.com \\ Received 5.04.2018
}

Topic and aim. The data on the latest achievements of authors on the development and investigation of field emitters for electron-beam microwave devices of millimeter and submillimeter wavelengths range are presented. Methods. The methods for creating and characteristics of new type cathodes, that are of great practical interest, are described: multi-tip silicon cathodes with two-layer metal-fullerene coatings and multilayer nano-structured cathodes, whose emission is determined by the fields at the contacts of materials with a different work function. Numerical calculations and experimental investigation were carried out to optimize the cathodes and to determine their emission characteristics. The most important features of the experimental setup used are as follows. The operative change of the pressure from the minimal value $10^{-9}-10^{-10}$ Torr up to $10^{-6}$ Torr and back is possible. $\cdot$ It is possible to carry out a number of technological operations directly in the vacuum chamber, including the deposition and treatment of coatings. - It is possible to study the emission characteristics of cathodes in the continuous and pulsed modes over a wide range of voltages (up to $15-25 \mathrm{kV}$ ) and currents (up to $0.5 \mathrm{~A}$ ). Results. A large number of new results have been obtained which particularly include: • fairly simple and reproducible technologies for creating multi-tip and multilayer emitters have been worked out; • the mechanism of functioning of protective fullerene coatings has been defined; - the optimal structure and morphology of the surface of multi-tip cathodes with 
metal-fullerene coatings have been determined and the possibility of obtaining the field emission currents up to about $100 \mathrm{~mA}$ with the current density up to $0.4 \mathrm{~A} / \mathrm{cm}^{2}$ has been demonstrated; • the optimal structure of multilayer hafnium-platinum cathodes was determined and the possibility of obtaining the emission currents of about $2 \mathrm{~mA}$ at an extremely high current density of about $200 \mathrm{~A} / \mathrm{cm}^{2}$ has been demonstrated; • the possibility of a long-term stable operation of the created cathodes at large currents in the conditions of at technical vacuum has been demonstrated. Discussion. Summarizing, it can be said that the created and studied cathodes are promising for use in miniature high-voltage electron-beam microwave devices of the millimeter and submillimeter wavelength range.

Keywords: field emission, multitip cathodes, multilayer cathodes, technical vacuum, ion bombardment, two-layered metal-fullerene coatings, fields of contact potential difference, short-wave electron-beam microwave devices.

DOI: 10.18500/0869-6632-2018-26-3-109-126

References: Sominskii G.G., Sezonov V.E., Tumareva T.A.,Taradaev E.P. Development of field emitters for short wave microwave devices and their investigation in SPBPU. The last achievements. Izvestiya VUZ, Applied Nonlinear Dynamics, 2018, vol. 26, iss. 3, pp. 109-126. DOI: 10.18500/0869-6632-202018-26-3-109-126 